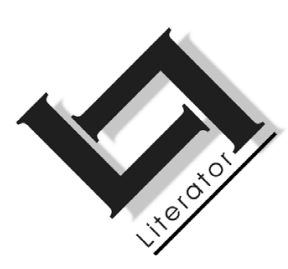

\title{
B.W. Vilakazi and the birth of the Zulu novel
}

\author{
N.N. Canonici \\ School of IsiZulu Studies \\ University of KwaZulu Natal \\ E-mail: canonici@ukzn.ac.za
}

\section{Abstract}

\section{B.W. Vilakazi and the birth of the Zulu novel}

B.W. Vilakazi is rightly famous for his Zulu poems that integrate the Zulu creative genius with established European poetic trends. He was also the creator of the Zulu romantic novel, having written the first three examples of the genre dealing with both personal and national romantic ideals. These are, however, seldom analysed. This article reflects on the emerging literatures in African languages, their aims, contents and forms. After a general introduction on Vilakazi's life and innovative approach to creative writing within the context of the African mini-renaissance period of the 1930s, there is a brief exposition of Vilakazi's vision of an African literature, rooted in the need for self-identification, and recognition of perceived historical greatness. Then each novel is contextualised and analysed, through a description of the characters that exert the greatest influence on the events, since plot and character are also the highest achievement of the folktale, when told by expert performers. An attempt is also made to identify Afro-centric narrative elements and to justify perceived shortcomings in plot construction.

\section{Opsomming}

\section{B.W. Vilakazi en die ontstaan van die Zuluroman}

B.W. Vilakazi is ten regte bekend vir sy Zulugedigte wat die kreatiewe Zulutalent integreer met gevestigde Europese poëtiese neigings. Hy is ook die vestiger van die romantiese roman in Zulu deurdat hy die eerste drie voorbeelde van hierdie genre geskryf het, waarin sowel persoonlike as nasionale romantiese ideale betrek word. Hierdie tekste is egter nog min geanaliseer. Hierdie artikel ondersoek die opkomende literatuur in Afrikatale, 
en die doelstellings, inhoud en vorms daarvan. Na 'n algemene inleiding oor Vilakazi se lewe en sy innoverende aanslag in kreatiewe skryfwerk binne die konteks van die Afrika-minirenaissanceperiode van die dertigerjare van die vorige eeu, volg 'n kort uiteensetting van Vilakazi se visie van 'n Afrikaliteratuur wat gegrond is op die behoefte aan selfidentifikasie en erkenning van verworwe historiese statuur. Elke roman word daarna gekontekstualiseer en geanaliseer deur 'n beskrywing van die karakters wat die grootste invloed op die gebeure uitoefen, aangesien. die uitbeelding van intrige en karakter in 'n volksverhaal (folklore) die hoogste gereken word wanneer dit deur bekwame uitvoerders vertel word. Daar word ook gepoog om Afrosentriese narratiewe elemente te identifiseer en om telkens waargenome tekortkomings in die konstruksie van die intrige te regverdig.

\section{Who is B.W. Vilakazi}

This article offers an overview of Benedict Wallet Vilakazi's life (1906-1947), followed by aspects of his literary work that place him in the historical background and justify his fame, especially in poetry. The favourable creative climate at the beginning of Zulu written literature in the 1920s and 1930s is characterised by a drive to artistically portray African problems, culture and history. Vilakazi embraced this challenge as his guiding light. His three novels are then analysed, paying special attention to Afro-centric elements expressed in them.

Vilakazi was born in Groutville, near the KwaZulu Natal border. He attended the local primary school founded by the famous American missionary and linguist Lewis Grout. He was trained as a teacher at Mariannhill under Father Bernhard Huss, an innovative educationist who upheld the validity of African culture and inspired students to scrutinise the western culture inculcated by the British-based school syllabi to identify and possibly integrate elements compatible with African traditions. The Mariannhill archives possess the manuscripts of the famous twelve dramatic sketches, created and performed by the students in 1921-1922, representing stories taken from the Bible, British history, and also notably African history and folklore. These are often considered the first examples of Zulu creative writing. The neat handwriting supposedly belonged to Vilakazi, who was acting as secretary to Fr. Huss during his student years.

Young Vilakazi (nicknamed Bhambada, because he was born during the Bhambada Zulu uprising of 1906) was fascinated by the English romantic poetry and novels, characterised by a return to an idealised 
past, an atmosphere of remoteness from everyday life, and a sense of wonder surrounding the mutual attraction in a love relationship. He made it his life mission to demonstrate that his own language, IsiZulu, was adequate to express the most profound human sentiments and the loftiest ideals, and that Zulu history contained heroic events capable of firing people's hearts to urge them to proudly identify with national heroes. He drew from both European and African forms and traditions to create genres, in both poetry and prose, which future generations could imitate, and be moved by. Vilakazi wrote in 1938 (quoted in Gerard, 1971:231):

If we imitate the forms ... of our Western masters, that does not mean that we have incorporated ... even the spirit. ... We employ the forms only as vehicles for our poetic images.

The positive reception of his first poems, initially published in newspapers and then collected in Inkondlo kaZulu (Vilakazi, 1935b), encouraged him to experiment with poetic forms, feeling that he was bringing to life a rejuvenated Zulu poetry. More laborious was his endeavour at novel writing, since its oral antecedent, the inganekwane (folktale), presented a very simple narrative form. Vilakazi's creations form part of the enthusiastic atmosphere prevalent during the third and fourth decades of the twentieth century.

\section{The early African Renaissance of the 1930s}

The 1909 Union of South Africa was a pact of the white races on the skin of the black populations to defraud them of their lands, traditional institutions, religion and culture, and thus make them unable to resist enslavement. Both the Louis Botha and the Hertzog governments institutionalised many discriminatory practices rooted in the colonial practice of the previous century, which deprived the Africans of basic human rights.

The African elite reacted to the oppression by finding its own political and cultural voice to vindicate its right of existence in its own country. The essential medium of cultural expression were the African languages, which H.I.E. Dhlomo (quoted in Gerard, 1971:228) described as having "greatly developed powers of speech" in their oral milieu. These were taught in several mission schools and studied in the emerging South African universities. James Stuart's Zulu readers (1922-1926), based on oral traditions, were widely used and fired the imagination of their readers, giving new impetus to proud self-identification. Energetic and well-educated people, such as John Langalibalele Dube, Thomas Mofolo, S.T. Plaatje and A.C. Jordan, 
used African languages to create literary works that reflected the African artistic traditions while absorbing and adapting some western forms. A wave of pride swept through the Southern African elite classes, accompanied by a creative spirit that found expression in the political and cultural arena (the African National Congress (ANC) and the Inkatha Zulu cultural movement). To be an African was no longer a handicap, but a privilege. And this had tremendous repercussions on the literary scene.

\section{The literary context}

Zulu literature ... falls into two distinct categories, one concerned with traditional Zulu life and history, the other with Christianity. ... These two broad areas were to combine in the 1930 's in imaginative literature, thereby producing the crucial conflicts which have profoundly concerned southern African writers for decades: the urban, Christian, westernized milieu versus the traditional African past. (Scheub, 1985:493.)

Vilakazi, the first Zulu novelist of note, created the genre by adapting foreign forms and Zulu literary traditions, and clearly expressed the conflicts identified by Scheub. He also tried to be "Afro centric" in his writings, to give expression to genuine African life and concerns. H.I.E. Dhlomo writes:

We want African writers who will dramatize and expound a philosophy of our history. We want dramatic representations of African oppression, emancipation and evolution. (Quoted in Gerard, 1971:229.)

Vilakazi matured as a scholar and artist in this atmosphere and contributed to it through his incomparable poetry, as well as by his fictional prose, which gave impetus to what Mathonsi (2002:62) calls "the early elite story", as it was created by the educated converted elite (amakholwa), to be perused by the schooled elite, and mainly explored problems of the elite. The racist colonial system was easily identifiable as the arrogant villain who tried to suppress anything good in African life. It was argued that the glorious African past proved that a great people could not remain enslaved for long: past greatness was a clarion call that demanded self appreciation in the present. Thus the romantic ideals Vilakazi had assimilated through his English readings urged his creative imagination to bring to life the best aspects of the Zulu past in his romantic novels and poetry. Or, as Chapman (1996:50) puts it, as a reusable tradition, capable of stirring the imagination of the present generations and to enthuse them into forging a brighter future. Also Mathonsi (2002:28) calls for 
heroes and geniuses to embody the values and aspirations of the people and serve as all-encompassing inspiration.

African history was only incidentally taught in schools until R.R.R. Dhlomo's books on the Zulu kings became available in the late 1930s. Vilakazi resuscitated history by creating novels to be a celebration of Zuluness (ubuZulu), of greatness and heroism, while exploring the extensive possibilities offered by the Zulu language (isiZulu). Any excuse was good to break into an illustration of Zulu life, sometimes by means of brilliant plot digressions, which often rendered the narrative heavy and episodic.

Vilakazi's written predecessors in Zulu written prose were few. Oral history, legends and folktales on one side, Christian values, urbanisation and moral decadence on the other, supply the subject matter of early IsiZulu writings. Fuze's and Dube's early output open the gates of the emerging Zulu fiction, while Vilakazi's mark its bright affirmation. All three authors are steeped in tradition, but are also mission-educated (amakholwa, believers). All three use the tribal past as an inspiration to find national roots, draw strength and resist the discriminatory practices of the day.

In my analysis of Vilakazi's three novels and of the characters that drive their plots I show his attempt, in the first novel, to integrate positive elements of traditional customs in a Christian context, while criticising half-baked converts. The second novel turns to early Zulu history and the transformation of the tiny Zulu tribe into a regional powerhouse; the third portrays a more recent glorious Zulu exploit.

\section{Vilakazi's three novels}

Vilakazi initially created a romantic story describing the difficulties of young lovers. This reflected peri-urban Zulu "new" life and the dilemma faced by new converts. Then, possibly urged by the success of R.R.R. Dhlomo's royal trilogy, he turned his attention to an idealised Zulu past as a source of national romanticism: Dingiswayo's pre-Shakan era and the glorious but unsuccessful uprising of his namesake, Bhambada kaMancinza. The tree novels are:

- Noma nini ("No matter when"; or "For ever") (1935). This is a romantic story set against the period of Mpande's reign (18401872). 
- UDingiswayo kaJobe ("Dingiswayo, son of Jobe") (1939). A romanticised story of Shaka's mentor, set in the early period of Shaka's career.

- Nje nempela ("Yes indeed"; or "Truly") (1943). A romantic novel against the background of the Bhambada Zulu uprising of 1906.

The novels are analysed by highlighting the role of the main characters and their actions and by briefly commenting on outstanding elements that reveal Vilakazi's concerns about aspects of African life.

\subsection{Noma nini (1935)}

The novel was written around 1932, and was submitted to the third competition of the International African Institute, which awarded it first prize in 1933. Imitating the English romantic novelists, Vilakazi chose a love theme, set in a Zulu milieu (the Groutville mission where Vilakazi was born and spent his early youth), and at a recognisable time in Zulu history, namely King Mpande's flight to Natal in 1837. Idealised romantic love is a possible departure from the generally perceived Zulu functional view of marriage as mainly aimed at the continuation of the male lineage.

The novel reflects an era of dramatic transition: the Christian mission proposes a revolution in the spheres of religion, education and social behaviour. The consequent insecurity is represented by Nomkhosi, the central character, whose name appropriately means "Mother of upheaval", and by her second suitor, Tomasi, a Christian convert unsure of his faith. Change is a constant challenge in life, and demands vision and courage.

Culture shapes the soul of individuals and society. It regulates every facet of behaviour, the roles of individuals as members of family, clan, nation; it embodies religious beliefs and practices, as well as methods to harness supernatural powers, for good or evil, by means of magic formulas and rituals. Urban life and its western environment are seen as a break from traditional culture and a threat to family, clan and tribal structures. The Christian mission and its school in Noma nini, or the Barberton shebeens in Nje nempela, are agents of social change.

\subsubsection{Plot and characters}

The novel begins with the flight into Natal by Mpande's faction to escape from Dingane, Shaka's successor and ruler of the Zulu 
kingdom. During the flight Makhwatha picked up an abandoned baby girl and adopted her, naming her Nomkhosi. British colonial Natal is seen as liberal in comparison to the strict and often oppressive customs and traditions in KwaZulu. The novel also offers the author the possibility of celebrating Groutville, his birthplace, and its founder, the missionary Lewis Grout, the agent of change.

After a lengthy digression on Zulu history, the story describes the growing love between young Nomkhosi and Nsikana. The two promise "Ukulindelana Noma nini" (To wait for one another no matter how long). Faithfulness for an indefinite period of time proves testing for the young girl; but for Nsikana - whose name is the diminutive of insika, the strong supporting pole of the rondavel - it entails unwavering commitment.

Nsikana quietly leaves for Durban to work and earn money for lobolo (bride's dowry), to be able to officially ask for his sweetheart's hand, and Nomkhosi hears nothing from him for a long time.

Nomkhosi becomes nursemaid to Rev. Grout's children. At the mission, Tomasi, the lay preacher, flirts with her and she soon falls under the spell of the westernised and good looking young man. Tomasi is the name of "Doubting Thomas" in the Gospel: a man insecure of his faith. The resulting love triangle forms the core of the romantic conflict, with Nsikana representing the traditional values of steadfast loyalty and uprightness, and Tomasi representing a rather superficial believer and confused lover, in spite of his leading position in the new society, the church. He hides his weak character behind the screen of status.

Nsikana renews his promise by sending Nomkhosi a beautiful scarf with the words Noma nini, and she realises that she still loves him. When Nsikana hears that Tomasi wants to marry Nomkhosi, he hurriedly sets off for home, but is attacked, robbed and left for dead at the roadside. He is picked up by the driver of the mission wagon, and by the time he recovers, it becomes common knowledge that Tomasi is about to marry Nomkhosi and the Grouts favour the match.

Nsikana's sister tries to convince him to forget Nomkhosi and marry someone else, but he won't hear of it. He craftily obtains Rev. Grout's support to realise his youthful promise, then confronts the girl to regain her love. She initially pretends not to recognise him, but love is soon rekindled through his kindness, handsomeness and gentlemanly manners. 
Tomasi becomes dead jealous when he realises he might lose Nomkhosi to Nsikana. He forgets that, as a Christian, he has renounced superstition and witchcraft and visits a famous Durban witchdoctor for love potions. He sounds really desperate:

Wo baba ngize kuwe, ngoba ngilahlekelwe yingoduso yami, ... manje isifuna ukuthanda omunye ... (Vilakazi, 1935a:123).

Father l've come to you because my fiancée has dropped me, ... and intends to love another man ...

In spite of external pressures, Nsikana refuses to resort to similar love charms, saying he has given up such practices by embracing the Christian faith. Vilakazi views Tomasi's return to witchcraft as a betrayal of his Christian conversion. Ultimately Rev. Grout, on his wife's advice, calls in Makhwatha, Nomkhosi's father. The old man asks the girls in the family how to solve the love triangle according to Zulu custom. Nontula, Nomkhosi's elder sister, forces the younger girl to make the final choice by arranging a meeting between Nomkhosi and the two suitors. Nomkhosi finally chooses Nsikana by handing him a beaded stick, a mark of love in the Zulu traditional way. Reusable customs resurface in a semi-westernised environment and win the day.

\subsubsection{Thematic elements}

Among the many plot digressions, meant as cultural and historical background information, one deals with a story of Nsikana's white employer about a war in Uganda, where he was saved from the jaws of a lion by his black attendant. Vilakazi proposes a racial harmony based on a spirit of mutual appreciation and understanding: life would improve if blacks and whites tried to understand and appreciate each other's culture, and to live in a spirit of mutual cooperation, respecting each other as human beings.

The main theme in the story, arising from the portrayal of a period of deep transformations, is "consistency in the turmoil caused by change". This is illustrated by the contrast between the steadfast commitment of Nsikana and the erratic behaviour of Tomasi. Nsikana is strong, because he knows who he is and what he wants. His morals amalgamate ubuntu and Christian values. Tomasi is a Christian when it suits him, but slides back into doubtful practices when his Christian faith does not produce immediate results. Nomkhosi, instead, is simply a fickle teenager at the threshold of life, unsure of herself, and therefore unsure on whom to bestow her favours. 
The novel illustrates the turmoil of amakholwa, torn between the old and the new. It maintains that tradition and westernisation need not be in opposition, but could coexist and even be integrated, since change is part of life, and it's normal for people to grow and mature, adopting the best elements offered by different cultures. The missionaries do not destroy the Africans' way of life, but try to enhance the good in it, as seen in the relationship the Grouts have with Makhwatha and also with Nsikana whom they don't really know.

The figure of Tomasi gives rise to another theme, which often reappears in later fiction, namely the corruption of some school teachers and church ministers who hide behind the mask of progress or religion. They become con-artists in deceiving devout followers, especially women, and in depriving them of their money, and often of their honesty and respectability.

\subsection{Udingiswayo kaJobe (1939)}

This can be identified as a historical novel, because the main characters (Jobe, Dingiswayo, Zwide) are historically attested and the narrated events had a bearing in shaping the history of the Zulu nation during the reign of Dingiswayo, the Mthethwa king, protector and mentor of young Shaka. The novel presents an idealised view of the pre-colonial past, when tribal life revolved around the royal household.

Vilakazi's historical interest, always alive, as attested by his poems, was probably further stimulated by the publication of R.R.R. Dhlomo's semi-fictional trilogy on the Zulu kings: UDingane (1936), UShaka (1937) and UMpande kaSenzangakhona (1938). Vilakazi aims to place Zulu historical events at the centre of the readers' imagination to reopen the national memory bank to build a renewed national pride and conscience, based on the perceived national greatness achieved before the arrival of the white colonists. This is top-down historiography in which the king is the heart of the nation, and his actions shape the national identity because they are shared by the entire population.

Oral traditions attest that Mthethwa King Jobe was afraid that his son, Godongwane, was plotting to kill him to obtain the kingship. He thus counter-plotted to have him killed at Yengweni. Godongwane, however, was warned by his doctor, Jevuza, and by his favourite sister, Dingiwe, and survived the ambush with only minor injuries. He escaped and lived for many years among the Hlubi, where he eventually met a white explorer who had a horse and a rifle, both 
unknown to the Mthethwa. With this white man he set off for Mthethwaland, and on the way he learned of his father's death. He killed the white man and proceeded, with horse and rifle, to claim the Mthethwa throne. With the support of Jevuza and Dingiwe he was recognised as Jobe's son and heir. On his enthronement he changed his name to Dingiswayo ("The needy one") and began to reign wisely. To strengthen his influence in the region he married two sisters of Zwide, the chief of the powerful Ndwandwe tribe. He brought about a number of reforms, organised a regular army, and also recognised and encouraged the ability of young Shaka. On the death of Shaka's father, Senzangakhona, Dingiswayo sent a battalion to install Shaka as king of the Zulu.

Dingiswayo understood the precarious position of his territory, squeezed between Portuguese Mozambique and the British Cape Colony, and saw the need to strengthen the Mthethwa to enable them to resist possible incursions from north or south. But Zwide was jealous of the rising power of the Mthethwa nation. He tried to destroy Dingiswayo by witchcraft, the coward's secret weapon. He got his own sister, Zenzile, to obtain personal effects with which to bewitch his opponent. Zenzile was power hungry and agreed to betray her husband Dingiswayo. The Mthethwa king fell into Zwide's magic trap and died in battle.

The historical elements in the novel play a major role, but it is still Godongwane's love life, and the jealousy between the two half sisters that he has taken as wives, that provide the romantic interest of the story.

According to Khumalo (1972), Vilakazi shows his deft artistry in portraying characters, revealed through their actions. The setting in ancient times allows Vilakazi to indulge in his pet interest, namely the power of magic to intervene in people's lives and even in the history of nations, often triggered by the jealousy of co-wives.

\subsubsection{Plot and characters}

In this analysis I loosely follow Khumalo's (1972) approach, who maintains that actions are the truest revelation of characters. The main actors in the novel are Godongwane (later Dingiswayo), around whom the story develops; Nobantwana, his first wife, full sister of Zwide; Zenzile, his second wife, Zwide's half sister (from a different mother), but a full sister of Malusi; Zwide, the Ndwandwe chief and the antagonist in the drama; and Jevuza, Godongwane's loyal doctor and advisor. Minor characters are Malusi, whose death 
causes the great Mthethwa-Ndwandwe war in which Dingiswayo is killed; Jobe, Godongwane's murderous father; Dingiwe, Godongwane's sister; and a few others. The incidents involving Shaka and Senzangakhona are only marginal to the plot, although they are of historical interest.

I shall follow the development of the plot through the actions of the main characters.

\subsubsection{From the Yengweni ambush to the Mthethwa throne}

The initial situation in the Mthethwa kingdom introduces the main characters, setting in motion the events that will end in the tragic denouement.

The initial disturbing event is King Jobe's ambush at Yengweni to kill his sons. Jobe is respected as a king, but is feared as a chronic and sometimes murderous somnambulist. He lives in constant fear for his life and is suspicious of those closest to him, especially his sons.

UJobe wayehloniphekile, ehlala kodwa ngokwenqena bonke abasondelene naye sengathi bengamenza kabi. (p. 3.) ${ }^{1}$

Jobe was revered, but lived in fear of assassination by those closest to him.

Jobe has heard from evil gossipers that his son Godongwane is constantly talking about re-organising the kingdom, and is evidently placing himself in a strong position to succeed him, although he is younger than the lawful heir, Tana. The king orders the killing of both Tana and Godongwane, but the latter is warned by his loyal doctor, Jevuza. He pretends to be dead and thus escapes with only minor injuries and flees the country.

Jevuza and Dingiwe (Godongwane's favourite sister) are both dedicated to him. Jevuza had earlier told Godongwane:

Ngofa lapho ufa khona, ngivuka nawe uma uvuka, ngilale nawe nasendle ezinkangala; uma ulele uhonqa mina ngiyobe ngiqwashile kuze kuse. (p. 11.)

$1 \quad$ References in 4.2.2 and 4.2.3 containing only a page number refer to Vilakazi (1939). 
I'll fight to death to protect you. I'll only survive if you survive; I'll be your companion even in the wilds, and while you sleep and snore, I'll remain awake and keep watch over you.

The portrayal of the characters of Tana and Godongwane makes it clear that, should they survive Jobe's ambush, Godongwane, and not Tana, will take over the kingdom.

Tana, the elder brother, is described as follows:

... uTana kungumuntu owayebukeka enganake lutho ngezindaba zemibuso. Into owayeyithanda UTana kwakungukuzingela, nokuzixoxela izindaba zokuntela. (p. 7.)

Tana did not seem to care for matters of government. All he loved was hunting and telling humorous stories.

Godongwane, on the other hand, was deeply interested in the nation's political life:

Nabantu eYengweni izindaba zemibuso babezixoxa kuGodongwane yena owayenamehlo ngazo ezithanda futhi. (p. 11.)

The men at Yengweni discussed public affairs with Godongwane, who had an interest in them and loved a good discussion.

Godongwane considers himself the leader of the Mthethwa. When Jevuza tells him to run away because his father wants to kill him, Godongwane asks,

Bathini bona abantu laba? Bathini bona uma bebona kubaleka umholi wabo kuqala? Bangethi ngibashiya emgebeni ingozi bengivele ngiyazi kodwa bona angabatshela? (p. 11.)

What will the people say? What will they think when their leader is the first to flee? Won't they say that I deserted them in times of danger, knowing the dangers surrounding them and yet not warning them?

Jobe had a premonition that Godongwane would be the next Mthethwa chief because, on his deathbed, we are told,

uJobe wabiza ibandla wavalelisa, wabeka umbheki wombuso wakwaMthethwa wathi kuyoba nguMawewe inkosi, owayezalwa ngomunye wamakhosikazi amancane okuthiwa amabibi. Akakhohlwanga uJobe ukulayeza ngokuthi uyabona ukuthi uMawewe akanakubusa ngokukhululeka ngoba uGodongwane akafanga, nokuthi kuyodingeka ukuba aqashelwa angaqambi 
inhlakanhlaka ngokwahlukanisa isizwe sakwaMthethwa, uma esebuya ekubhungukeni, uma eyoze wabuya. (p. 19.)

Jobe summoned the court and bade them farewell, appointing Mawewe, the son of one of his junior wives (called amabibi) as king of the Mthethwa. He expressed the fear that Mawewe would not reign in peace because Godongwane had not died. He requested the court to be on the look out for Godongwane, to make sure that he would not split the Mthethwas in two when he returned from his banishment, should he ever return.

Godongwane does indeed return, and with Jevuza's assistance, kills the recently appointed Mawewe, takes over the Mthethwa throne and assumes the name Dingiswayo.

\subsubsection{Co-wives' jealousy and the showdown in the Ndwandwe- Mthethwa war}

Dingiswayo introduces many reforms and strengthens the army to withstand dangers from north and south. His growing popularity and regional power stirs Zwide to a frenzy, because the Ndwandwe king cares more about his personal power than his nation. The stirrings of the war in which Dingiswayo finally dies are sculpted in the personalities of the characters involved.

The trouble is described more as a family squabble than a national misadventure. Dingiswayo had taken as his chief wife Nobantwana, Zwide's full sister and his own childhood sweetheart. Through this political marriage Zwide intended to control Dingiswayo through his sister. But Nobantwana did not play Zwide's game. Dingiswayo, however, fell madly in love with beautiful Zenzile, his second wife, Zwide's half sister and a full sister of Malusi.

UZenzile lona, naye wayenobuhle bakwabo ethatha, noNobantwana engezi lutho. (p. 98.)

Zenzile was also a very attractive woman, competing with Nobantwana in beauty.

When Zenzile arrived at Dingiswayo's home he was immediately taken by her feminine wiles,

... ngokuzithoba kwakhe nangendlela yokubuka kwamehlo akhe (p. 99).

... because of her reserved behaviour and the way she moved her eyes. 
This infatuation with Zenzile was taken as an affront by Zwide, who then took indirect revenge on Dingiswayo by destroying Malusi's homestead, knowing this would provoke Dingiswayo who, to console his distraught wife Zenzile, went to war against Zwide.

It was Dingiswayo's bad luck to fall madly for scheming Zenzile rather than loyal Nobantwana, and thus make possible the enactment of Zwide's destructive plans.

Zulu custom allowed Dingiswayo to take two sisters as wives. But Zenzile had to remain subordinate to Nobantwana, the chief wife. However, Zenzile was self-centred, ambitious, power-hungry and lazy, wanting to be the Queen, Number One rather than Number Two. She quickly shed her self-effacing ways when she became Dingiswayo's favourite. When her brother, Malusi, was killed, we read,

UZenzile kuthiwa wakhala lonke isonto ezivalele kwakhe, engafuni ukubonana namuntu ngisho inkosi uqobo Iwayo. Mhla ifika ingena ngenkani ... (p. 101).

Zenzile is said to have cried a whole week, shut in her room, and refusing to see anybody, even the king himself. When he forced his way in ...

This shows arrogant behaviour, most un-African in a wife. She even challenged Nobantwana's authority and status as senior wife.

Kanti lapha kulo muzi ubani ofanele ukushayela imithetho isifazane sonke silalele yena? (p. 123.)

Am I not the one who gives orders to all the women in this home?

Being completely self-centred and seeking only personal advantage, she had no qualms of conscience to betray her husband Dingiswayo by stealing and handing over to Siqongo a bead necklace, which Siqongo and Maguduza used to cast a spell on Dingiswayo during the war.

Dingiwe (Dingiswayo's sister), a sober judge of character, summed up Zenzile:

Ehhe, uZenzile uliqhalaqhala uyimbongi yokwakhe, uzikhothe emhlane, sonke akasazi ukuba singobani. (p. 161.)

Yes, Zenzile considers herself the star here, and despises all of us. 
Nobantwana, on the other hand, was a retiring woman, unassuming and hard-working. She got up early to work in the fields, and the people who met her were surprised.

Indodakazi yenkosi yakwaNdwandwe, iganele enkosini yakwaMthethwa, //ukuvuka ngalesi sikhathi iyolima! Kwakumangalisa! (p. 163.)

The daughter of the Ndwandwe king, married to the Mthethwa chief, getting up so early to go to work in the fields! What a wonder!

Her unassuming nature made her easy meat when she quarrelled with Zenzile.

Okwenkosikazi enkulu lapha eBalungwini, mina wakoNdwandwe angikwazi ngoba angizanga lapha ukugana, ngazohlalela ukubukana nobukhulu, ngezela ukugana kuphela. (p. 172.)

I, the daughter of the Ndwandwes, am not interested in who is the senior wife here at Balungwini. I came here simply to be a wife - not to fight over seniority.

Malusi was a pawn in Zwide's plan to get rid of Dingiswayo. Zwide wiped him out to force Dingiswayo into war. Zwide's plan worked, but the harm caused to the Mthethwa nation stirred the fire of revenge in the heart of Shaka. Zwide's victory marked the beginning of his downfall.

Zwide was unscrupulous and ambitious. He is depicted as manipulative and callous. His initial plan to gain the Mthethwa power misfired, because Nobantwana was too honest and straightforward to fall for her brother's schemes, to enable his witchdoctors to exert magical powers over him. Zwide revealed his plan to Malusi when, in discussing the threat of the rising might of Godongwane and the Mthethwa kingdom, he said,

Mina ngibona linye icebo mfowethu. Noma umuntu esenamandla anjani kuhle umthumele inyoka iyombulala, imbulale endlini lapho engabheke ngozi khona. (p. 93.)

I have only one plan, brother: to send a snake to kill the man no matter how powerful he is - in his own home, where he least expects danger.

This "snake" was evidently meant his sister, Nobantwana. She was supposed to destroy Godongwane as her marriage would seal a 
blood relationship that rendered war improbable; then by allowing Zwide to become regent of the Mthethwa kingdom for her child at Godongwane's death.

Zwide's vile plan failed, but was replaced by Zenzile's ambition and disloyalty. Zwide was completely without human feelings. When he was told that his favourite daughter, Maguduza, was possessed by the ancestral spirits, he went to her:

Wafika qede wambona elele phansi ethe ja. Wambuka ephefumulela phezulu okwenkabi igwazwe ngomkhonto yawa phansi, kuthi ma iphefumula kuphume igazi ngenxeba, uyizwe ibubula njalo ilele. NoMaguduza wayephefumulela phezulu ngomlomo kuphuma amagwebu, esifubeni sakhe kube khona njalo izinto esengathi ziyagqigqizela zibanga umsindo. (p. 95.)

He immediately saw her stretched on the ground, breathing painfully like a stabbed ox, which, when it breathes, spurts blood through the wound as it lies there, groaning. Also Maguduza was breathing heavily with foam coming out of her mouth and strange sounds rumbling in her chest.

Zwide showed no concern about his daughter's health, but was only interested in using her to fulfil his plans to destroy his rival king. In fact, Maguduza had become a powerful diviner, and spoke of Sinqongo as being willing to assist her in treating Dingiswayo's soldiers to weaken them in battle, Zwide showed his joy.

uZwide wahlala phansi, wezwa inhliziyo yakhe igcwala umoya wobuqhawe nokunqoba, wabona iMfolozi emnyama neMfolozi emhlophe igcwala amakhanda ezinsizwa zezizwe ezazingathandi ukukhonza kwaNdwandwe zibheke yena njengenkosi yazo. Waphonsa amehlo buqamama eNingizimu wabona amaZulu nezicocwana zawo. nabakwaMthethwa neZulu lawo likaGodongwane, wabona abakwaMpanza nabakwaMahlaba nabagemaMbatheni -beguqe phansi kwakhe. bekhothama bethi.' Bayede! (p. 132.)

Zwide sat down and was filled with a sense of boldness and victory. He saw the Black and White Mfolozi rivers filled with the bodies of his enemies. He cast his eyes towards the south and saw the Zulu with their small headrings; the Mthethwa with Shaka; the Mpanza, the Mahlaba and the Mbatha, all prostrating before him, bowing and saluting 'BAYEDE!' 
Zwide only cared for himself and his personal power. His favourite daughter was only useful as a stepladder to the attainment of his goals. War against Godongwane was therefore inevitable.

\subsubsection{Dingiswayo's death}

Dingiswayo's death is a very touching drama, fit for the stage. One of Zwide's soldiers has mortally wounded Dingiswayo. He lies bleeding, calling in turn for Jevuza, his beloved doctor who saved him from his first stab wound, and Nobantwana his wife and boyhood sweetheart. Zwide is summoned to the scene. Dingiswayo's dying face shows no hatred; he accepts death from the hands of fate. Dingiswayo stretches a hand towards Zwide, who rushes to take it and supports him with the other, as his rival is no longer a threat. Zwide appears to see only his sister's dying husband and says:

Hhawu mkhwenyana. bengingakuqondile mina lokhu. Yingozi Mthethwa. Yingozi. (p. 146.)

Sorry, my brother-in-law; I did not intend this. It is an accident, Mthethwa!

Is this real sorrow or pretence? The drama is complete, but Dingiswayo's death stokes Shaka's fire for destructive revenge.

\subsubsection{African narrative motifs in the novel}

UDingiswayo kaJobe marks a break from the simple romantic novel in Noma nini. In fact, it deals with idealised African history, largely gathered from popular legend. Thus, it has to be expected that motifs of African orature, such as the following ones, appear in the novel.

- In Zulu oral narratives the moral of the story is rarely stated. Every listener reflects on the events and draws personal conclusions. In this novel Vilakazi hints at several points of reflection without stating them openly (Msimang, 1986). I identify the following:

- Succession fights in royal families, often between the righthand and the left-hand houses. Such squabbles are sometimes settled by the appointment of an outsider whose claims to the kingship are supported by powerful insiders - as Jevuza and Dingiwe do for Godongwane, who is believed dead, or lost in distant exile. The fact that Godongwane changes his 
name to Dingiswayo on his installation day, and that he introduces many new ideas and reforms might indicate his false identity to anyone able to see through the veil of legend (Argyle \& Preston-Whyte, 1978).

- The dangers caused in political and polygamous marriages by jealousy and envy of co-wives, who may be influenced by external interests to destroy their husbands.

- Internecine fights for local supremacy, involving even the closest circle of family, relatives and friends. One could say: "With a wife (Zenzile) and a brother-in-law (Zwide) like his, does Dingiswayo need any enemies?"

- Playing the "magic card". Fear of black magic renders Dingiswayo's army powerless. They are easily defeated and their king slain. Such fear is a powerful weapon in many societies and creates havoc. Zenzile helps Zwide and associates to bewitch Dingiswayo and his army, and thus triumphs over her own rival, Nobantwana. Witchcraft at Zwide's court forms the core of a 1979 play, UNtombazi, by Dladla. Ntombazi, Zwide's mother, is a powerful witch who, by magic, destroys her son's enemies, including Dingiswayo. But Shaka eventually defeats her and Zwide by force of arms aided by more powerful magic.

Elements of magic are also present in the third novel.

\subsection{Nje Nempela (1943)}

This historical romance is set against the background of the 1906 Bhambada Zulu uprising, called Impi yamakhanda ("War of the heads"), because the final straw was the imposition of a poll tax on the head of unmarried men, or Impi kaBhambada (Bhambada's War). It is historical in a wide sense only, since the main characters are fictitious. Some critics judge this as possibly the best of Vilakazi's three novels, in spite of its shortcomings in plot construction, where the historical and the romantic events run parallel with limited reciprocal influence.

The author celebrates the heroism of Bhambada, son of Mancinza, of the Zondi clan, the leader of the uprising. Vilakazi was nicknamed "Bhambada", because he was born in 1906.

I use the spelling Bhambada rather than "Bhambatha" (except in direct quotations) because this is the name used by amaZondi in the izibongo (praises) of their royal ancestor, where the hero is de- 
scribed as "striking viciously" (ubhambada) his opponents. The widely used spelling uBhambatha (from ukubhambatha) merely signifies a mother's "molly-coddling", or soothing her baby (Magwaza et al., 2006:6).

\subsubsection{The plot}

The fictional romantic hero is Malambule, who sometimes interacts with historical characters. The plot starts briskly, then makes a long digression on the shift taking place in the economic capitals of the country, the mining towns of Barberton and especially Johannesburg, where barter economy is changing to a money economy. To counter the lure of the gold mines that attract many able-bodied men and deprive the Natal farmers of manual labour, the colonial government introduces a poll tax, considered humiliating by the proud Zulu: they are not animals to be counted by their heads. There ensue antigovernment skirmishes and ambushes which climax in a general uprising led by Chief Bhambada.

Malambule arrives on the scene from the Barberton gold mines to support Bhambada. He spends a few days in the Nxumalo homestead due to illness. He is attracted by Nomcebo, one of Nxumalo's young daughters, but she is upset, because Malambule tries to court her in her own home, as he, used to a mining town life, does not understand the finer points of Zulu etiquette. During an exchange Nomcebo asks the question that becomes the title of the novel, "Wena ungubani nje nempela?" (p. 43) (But as for you, who are you really?). The title of the novel contains aspects of the theme: the search for one's identity, especially important in a period of sociocultural turmoil. In typical Zulu fashion, Nomcebo does not accept Malambule's advances right away, but her half-sister, Bhembesile, falls for him, and Bhembesile's mother uses witchcraft to ensure her daughter's success.

The otherwise peaceful courting scene is disturbed when chief Soshishili sends out scouts to procure beautiful girls as wives for his son. Nomcebo tries to hide by dressing up as a hideous monkey, but is discovered and taken to the chief's homestead, together with her jealous half-sister. Malambule's brothers kidnap her from there and take her to Malambule's.

Eventually Bhambada is killed and King Dinuzulu is imprisoned for having supported the uprising. Malambule returns from the war, and, with his father, turns crown witness against King Dinuzulu, accused of subversion by the colonial government. After the trials, Malambule 
elopes to Natal with Nomcebo. His war-hero status has fired the heart of his young lover; the girl who initially was a strong defender of Zulu customs and traditions, finally agrees to follow Malambule to a "new country" and without his paying any lobolo. This considerable shift in social values is indicative of the transformations taking place in the society. The anti-colonial revolt has caused a dramatic upheaval in the rules that traditionally regulate Zulu society; the trial of the rebels and the severe penalties meted out to them and to King Dinuzulu mark the end of the popular perception that an African tribe could overcome the military might of the British Empire. With the flight into Natal the young couple demonstrate Vilakazi's vision that the kingdom of KwaZulu and its strict traditions are the past, and the western ways of Natal offer some hope for a peaceful future.

Vilakazi's portrayal of the turn-coat central character is unsettling, to say the least. Malambule's co-operation with the colonial government against his own people is utmost betrayal, at least in the eyes of our generation. Vilakazi, however, had expressed the opinion, in his poem Khalani maZulu (1935), that peace is the supreme social good and that armed revolt had proved futile, even when led by figures as capable as Cetshwayo or Bhambada. Only peace can guarantee progress and prosperity.

\subsubsection{Shortcomings in plot construction}

Khumalo (1972:12) maintains that Nje-nempela presents the worst plot construction of Vilakazi's three novels, because the historical events of the Bhambada uprising and subsequent trial of King Dinuzulu and other Zulu leaders are not integrated in the novel's romantic plot. In the preface (Ibika), Vilakazi (1943:7) states,

Kule ncwadi ngibhala indaba yothando Iwensizwa nentombi Ukuyibhala kwami ngiyilumbanisa nodaba olukhulu Iwempi kaBhambatha kaMancinza ... okaMancinza ngimbeke kule ndaba ngoba ezinsukwini zanamhla siyakhohlwa yilabo abafa, befela umqondo ongenakumbululwa muntu uma thina babhali abamnyama singawumisi phambi kwezinye izizwe. Khona kuyothi noma sesafa kuthiwe sasizalwa ngamaqhawe.

In this novel I write of the love of a young man and a young woman. I place the story in the context of the great Zulu uprising (Bhambada's war). Mancinza (Bhambada) is celebrated because we tend to forget the heroes who died for certain ideals. Such ideals will never be appreciated by strangers unless we, the black writers, explain what motivated our heroes into taking the stand they took. So that, even after 
we are dead, it should be remembered that we were born of a stock of heroes.

Therefore the romantic events form the core of the novel, while, for the history of Bhambada. Vilakazi uses the verb ukulumbanisa, (to place side by side). He is, therefore, aware that the incidents do not merge into a tight whole.

The way Vilakazi explains the inclusion of the 1906-1908 events shows uncertainty about the nature of the historical novel, which must develop around historical characters, with historically verifiable consequences. Vilakazi, however, gives a non-literary reason for including the Bhambada uprising: to preserve its memory for future generations, so that they should remember and be encouraged by the fallen Zulu heroes; that outsiders should understand the motives that drove them to take a rebellious stand. In other words, he aims to record a glorious African event for patriotic and educational purposes. This praiseworthy aim would have been better served had the material been properly integrated with the fictional events. In the following sections I analyse the main characters in the romantic story as shown by their actions.

\subsubsection{Nomcebo}

Her name derives from umcebo (wealth), a celebration of the fact that, at her birth, her father returned from the Johannesburg mines with a lot of money. Due to her beauty, she is expected to increase the family wealth when lobolo is paid for her marriage. She appears childishly innocent as she runs towards Malambule, a stranger, to warn him to be aware of dangers. Her simplicity shows a character grounded on solid traditional values. When Malambule courts her for the first time, she reacts strongly and asks:

Uma ungibuka nje, uthi mina ngingowokuthanda wena? Wena ungubani? Uthi ngoba ulapha kwethu sikutholile udlula ngendlela bese uthi ngoba ugozobaliswe ukugula, abadala bengekho, wena-ke usuthola ithuba lokungeshela khona lapha kwethu? Wena ungubani nje nempela? (p. 42-43.) ${ }^{2}$ (Bold NNC.)

Look at me: do you think I should fall for you? Who do you think you are? Just because you are in our home and we've

2 References in 4.3.3-4.3.6 containing only a page number refer to Vilakazi (1943). 
welcomed you as a visitor, and you've taken shelter here in the absence of our elders while you are unwell; you are now taking the liberty to court me in my own home? But who are you, really?

Malambule does not expect such a rebuff from a young female, who considers a declaration of love a serious matter and not a whimsical flirtation, and now asks him for his moral credentials, as she considers an insult to be courted in her own home. Malambule, coming from Barberton, a gold-rush town and a melting pot of cultures where traditional customs count little, doesn't see anything wrong in his advances. The Barberton shebeens are happy hunting grounds for the miners, and centres of a fast and often irresponsible life.

Nomcebo's youthful and volatile character is further revealed when she hints that she is secretly attracted to Malambule, after having rebuked him, as she sadly remarks:

Uyajabula uyahamba kusasa, usuyobona abakini. (p. 57.)

You are glad to be leaving tomorrow to go to see your family.

She is sad at the thought that he should leave her, after declaring his love. She is immature, ignorant of the ways of the opposite sex and unsure of her own feelings.

The girl initially upholds her traditions, the only moral space in which she feels safe, then gradually breaks them as a sign that she is growing and maturing as a woman. Even her wearing of baboon skins, associated with witchcraft, is unthinkable in traditional terms. And her refusal to marry chief Soshishili's son is a declaration of independence from her parents and customs. She eventually agrees to go to the chief's place as a ruse, after being assured that Maphulana and Malambule's brother will snatch her away. Her acceptance to follow Malambule without any lobolo shows her greatest break with tradition and a leap towards a new world and social order. She embraces a new life, forgetting the wealth (umcebo) she is supposed to bring to her family by the venerated lobolo practice that establishes a woman's value in the face of society and guarantees the stability of marriage, but also makes the woman the husband's property. She declares that there is a wider (possibly freer?) world beyond the restricting horizons of KwaZulu. 


\subsubsection{Malambule}

Malambule is not a solid character. He has lost touch with customs and traditions that constitute the spine of a meaningful life, as revealed by his ignorance of etiquette when he courts Nomcebo in her home and again when he tries to involve Zazini, Nomcebo's brother, in courting her on his behalf. Zazini is very annoyed and retorts: "Wena kawuzesheleli ngani yena?" (p. 26.) (Why don't you court her yourself?) His life is completely divorced from traditional Zulu values, as he declares: "Sisazi yini thina lokhu sesijwayele elabeLungu elinomusi nothuli ..." (p. 13). (How can we know anything like this? We are now used to the western ways.)

Malambule's weak character is shown in his hesitation to respond to the call of the rebel Zulu leaders: "Lapho uMalambule uvalo Iwalungasamphethe kwase kuthi makawe phansi." (p. 142.) (At that moment Malambule felt a deep fear that rendered him almost powerless.) He eventually joins the uprising, as long as things go well.

But he is spineless and finally defects to the whites for fear of their detecting powers (p. 178-181). This is nothing short of high treason. Malambule personifies the unsettling times of transition, when black traditions and culture undergo deep transformations in contact with western ways. Having no proper roots, Malambule is ambiguous, double-faced, insecure about his national and personal identity: neither meat nor fish. He tries to show off as a typical Zulu isoka (young lover), a fearless soldier, relentless in the chase of a lover, but is eventually chastened and crestfallen. His behaviour changes drastically when he is groomed by Maphulana, who criticises his courting methods and tells him to be humble and to belittle himself in front of the girl, not to be pompous, nor to advertise his hero status. Eventually Malambule says:

Nomcebo ngiyakuthanda, konke okwami ngikunika wena, ngingenalutho nokho ngizinika mina uqobo Iwami, noma ngingumuntu wezizwe ongamaziyo, kodwa abadala bathi 'induku enhle egawulwa ezizweni', nami ngilandela izinyathelo zabadala. (p. 56.)

Nomcebo I love you, and I surrender everything I have to you. Indeed I'm placing myself in your hands; even though I'm a stranger you know little about, as the elders in their wisdom say: 'You must look further than your nose to make a sound choice', I too shall therefore follow in their footsteps. 
This loving confession, however, contrasts with his surprising distance towards Nomcebo when she is finally brought to his home. Now that the chase is over, perhaps Malambule takes her for granted, as a traditional family head who wants to establish his authority. He doesn't seem to appreciate Nomcebo's traumatic decision, who, by accepting to elope with him, has taken a gigantic step against all her strongly held convictions, solely for love.

In Malambule's character Vilakazi shows how easily urban blacks lose their true identity as they forget their traditional culture on which identity is based. They thus appear as persons of loose morals to rural traditionalists: a theme exploited in numberless narratives during the succeeding decades.

\subsubsection{Maphulana}

In the rural setting of the Nxumalo household, Vilakazi could not fail to introduce magic and magicians to solve difficult situations. As his name indicates (from ukuphula, "to break open suddenly", "to bring to light"), Maphulana is a mediator in the story, the personification of traditional powers of vision and healing, although he was not trained as a herbalist or a diviner, but picked up the skills by observation and practice. He hides behind the family fool (isilima) mask not to arouse suspicion.

At Nxumalo's place he is adopted as a lowly servant, although he had served as one of king Cetshwayo's stewards. He had been in love with Nomcebo's mother in their youth, but, with no cattle to marry her, he stooped to the servant role to remain close to her and guard over her family. He confirms his powers when he tells the family:

Qha ningabuye nesabe, kusuka namhlanje nizolala ubuthongo. Le mithi enginiphatha ngayo yizinsizi zamakhosi, kakudlalwa ngazo. (p. 77.)

You have nothing to fear at all; as from today you'll enjoy peaceful nights. I'm using the renowned magic from the greatest spirits to help you. It is no joking matter.

Women and medicine do not combine in Zulu culture, therefore he is not married and his relationships with women are regulated by a number of taboos. He has accepted sexual restrictions to ensure the efficacy of his magic. He also pretends to be a diviner, as when, having received secret information, he uses his bones to foretell the coming of Malambule's brothers to fetch Nomcebo: 
Ngiyazi ukuthi wena awusiye uMalambule uthunywe nguye. Ngikwaze lokho ngaphambi kokuba ufike lapha, nokuthi kukhona ibutho lezinsizwa ofike nalo. (p. 94.)

I know very well that you are not Malambule but have been sent by him. I knew it before you arrived here and also that you brought along a group of young men.

Maphulana is good at creating an aura of mystery, which affords him an advantage over people ignorant of the magical arts who are prepared to believe in anything.

Once he is sure that Malambule's intentions are honourable, he becomes his confidant, and guides him through the maize of Zulu etiquette and courting practices, so that the "stranger" may be successful in his love pursuit. In fact, Nomcebo responds positively to Malambule's new approach and Maphulana is eventually accepted as a father figure by the couple.

\subsubsection{Nxumalo's wives}

These are secondary characters, sketchily outlined, and yet they offer the author a chance to indirectly express his opinion regarding the touching subject of polygamy. The highest aim in a Zulu person's life was the continuation of the lineage, so that a man could be surrounded by a large family working for him in life, and become an ancestor to be remembered and venerated in family worship for generations to come. To ensure his prosperity in life and immortality in death a man endeavoured to have many children, and this was rendered feasible if he had many wives to bear them. To obtain wives he needed cattle for lobolo, the dowry to be exchanged for each woman. Thus the number of wives and children bore witness to his wealth and social standing. The process of lobolo negotiations was surrounded by rituals that ensured the ancestors' sanction and blessing, since life is granted by them. The final result, however, was seen by most men as acquiring full ownership of a woman, her person, her sexual and working services, and especially her children. The woman thus became the property of a man, useful as a child-bearer and minder, as household worker. Nsikana, in Noma nini, refuses point-blank to even consider polygamy, because he respects Nomkhosi and she occupies his whole heart.

A polygamous society was supposed to be strictly regulated, so that the husband would divide his favours equally among all his wives, while these attended to the tasks assigned by the chief wife without interfering with the others. But women have stereotypically been 
cast as able to twist a man's heart with their little finger. Hence jealousy and envy among co-wives often led to the use of poison or magic practices to solve family squabbles, or to ensure the headship succession for one's own son.

In UDingiswayo kaJobe, Godongwane's second wife is constantly fighting to control household affairs. She even obtains the king's personal effects to be used for his destruction. In Nje Nempela Nxumalo's two wives fight to ensure a desirable husband for their respective daughters to the point of employing black magic against their rival. As Maphulana confesses, "Women and magic do not mix. To remain a powerful magician one must avoid sexual contact with women."

Some aspects of Nxumalo's wives are reflected in their daughters, Nomcebo and Bhembesile, as they fight for Malambule's love. Initially the wives show completely opposite attitudes towards the customary duty to travellers and strangers. While Nomcebo's mother is kind, and agrees to look after Malambule in his illness, Bhembesile's mother is suspicious and even venal. She says:

Qha njengoba lo mkhuhlane uthathelwana, ngiyesaba ngalo muntu. Uma uvuma pho singalokhu sikhathazwa yilo muntu wezizwe singethole lutho ngaye. (p. 31.)

Since this disease is infectious, I am afraid of this man. I don't know whether you'll agree with me. But why should we be concerned with this stranger, from whom we shall obtain no gain.

Nomcebo's mother quickly retorts by quoting ancient proverbs, on which all life is based:

Kodwa pho, abadala babeqondisani uma bethi kubantwana, 'Ukuhlwa kokuqoqa', babuye bathi, 'Unyawo alunampumulo'? (p. 52.)

What did the elders mean when they told their offspring to conduct themselves properly because they will return in times of trouble; and that one never knows where one's foot will take him or her [the foot has no nose]?

In spite of her initial animosity and mistrust of Malambule, Bhembesile's mother is later prepared to go to all lengths, even resorting to witchcraft, to ensure that he marries her daughter. This parallels Tomasi's actions in Noma nini. It is Maphulana that saves the day for Nomcebo and her mother. 


\subsubsection{The role of magic}

Thomas Mofolo's Chaka (1925) had made use of the traditional belief that black magic could be used to destroy human life and that offended ancestors could be turned, from benevolent tutelary spirits, into vengeful agents of fate. Sibusiso Nyembezi researched (1971) Vilakazi's use of magic in his novels and concluded that the writer secretly harboured a belief and possible fear of traditional magic practices.

It seems to me, however, that Vilakazi, a convinced Christian, uses magic as a literary device, as Renaissance poets invoked Greek mythological characters without believing in them. Furthermore, Vilakazi does not recognise real power for magic to shape historical events, but only considers it as a fear-inducing technique that deepens the sense of mystery in the face of destiny by exerting a powerful influence on those who believe in it.

Thus Dingiswayo's army is not defeated because it has been treated with magic medicines by a hostile witchdoctor, but because, at the first difficulties, the soldiers believe that the witchdoctor's treatment has rendered them powerless. There is no greater fear than fear itself. Superstitious beliefs take away the mind's power, rather than bestowing physical power on enemy assegais.

Also in Noma nini the power of the love potion is only in people's minds. Nsikana refuses to use it or to believe in it and eventually wins the love contest. Tomasi uses it and believes in it, but the magic potion does nothing in his favour. In Nje nempela Maphulana is presented as a herbalist (not a witchdoctor), who uses traditional medicines for the protection of those in his care. Herbal remedies are not magic means, no matter what gullible people may believe. Maphulana also pretends to be a diviner in order to protect his protegés, but he uses knowledge secretly acquired in a normal way to inspire confidence in his audience.

\section{Conclusion}

Historical and educational circumstances propitiously led Vilakazi into becoming the modern bard of the Zulu nation through his poetry, and the creator of the Zulu romantic novel. He revived and radically transformed the Zulu narrative tradition of izinganekwane. Vilakazi's three novels demonstrate a gradual growth from personal to national romanticism; from self-identification as a person, to self-identification as a glorious nation. This happened because he was fired by great 
exploits in Zulu history, which he compared to the English romantic novels read since his school days.

From Zulu oral traditions he drew the historical elements that formed the background inspiration for his novels, aimed at glorifying heroes and events that could focus his readers' self-identification. From his language and culture he borrowed a wealth of traditional images, expressed in carefully crafted diction, idioms and sayings that reflect all aspects of culture and ways of life. Khumalo (1972:19) states:

No author to date even approaches the poetic excellence of Vilakazi's diction. He picks the strings on the reader's heart as on an instrument when he is at his best. His diction is at its best in some of the sections which should never have formed part of the plot (e.g. chapter 7 in UDingiswayo kaJobe and chapter 3 in Nje nempela).

African narratology taught him the craft of multiple-layer plot construction, where various plots may develop independently and in parallel fashion, to meet only occasionally in the surface narrative, and yet mutually influencing one another throughout.

This is evidenced in UDingiswayo kaJobe, where the protagonist's own adventures are presented as an important preparation for Shaka's arrival on the historical scene to lay the foundation of the kingdom of KwaZulu. The method becomes even more evident in Nje nempela, where the secondary plot illustrates the heroic events of the Bhambada uprising, depicted by colonial commentators as an infamous and shameful chain of events. The Bhambada campaign still fired the hearts and the imagination of committed Zulu leaders, who were looking at history from an African perspective. Vilakazi's creative artistry had been refined through years of reading, teaching, writing poetry and prose, and his mastery of language by his research, while working with Prof. Doke on the monumental Zulu dictionary (1947).

The most telling departure from oral narrative is Vilakazi's mastery of characterisation. He believes that "A man's character defines his destiny". Major and minor characters are carefully drawn to reveal their respective function in the development of plot. Names of fictional characters are chosen with great care to highlight a person's characteristics, according to the Zulu traditional belief that a person's name indicates his/her life role, since the ancestors suggest the name before the child is born. 
The limited African Renaissance period of the 1930s both influenced and was influenced by Vilakazi's work as a poet, a novelist and a scholar. He contributed a joyous celebration of the epic events in Zulu history, told in James Stuart's series of Zulu readers (19221926), and especially in R.R.R. Dhlomo's semi-fictional lives of the Zulu kings. Also H.I.E. Dhlomo's English writings, which deeply reflected Zulu diction, imagery, culture and Afrocentric approach, moulded the way of life, culture and politics of the black and white intelligentsia, in preparation for the stirrings of independence that were to surge vigorously in the 1950s, to be savagely gagged by the Rivonia Trials of the 1960s.

Vilakazi died in 1947, at the age of 41 : a truncated branch laden with ripening fruit, a dawn pregnant with promise. But his pioneering work, in spite of the limitations consonant with all initial stages, was a seed that slowly came to maturity and bore an abundant harvest.

\section{List of references}

ARGYLE, W.J. \& PRESTON-WHYTE, E. 1978. Social system and tradition in Southern Africa. Cape Town: Oxford University Press.

CHAPMAN, M. 1996. Southern African Literatures. London: Longman.

DLADLA, A.H. 1979. UNtombazi. Pietermaritzburg: Shooter \& Shuter.

GERARD, A.S. 1971. Four African literatures: Xhosa, Sotho, Zulu, Amharic. Berkeley: University of California Press.

GERARD, A.S., ed. 1993. Comparative literature and African literatures. Pretoria: Via Afrika.

KHUMALO, J.M.S. 1972. Plot and character in Vilakazi's novels. Limi, 14:1-22.

MAGWAZA, T., SELETI, Y. \& SITHOLE, M.P. 2006. Freedom sown in blood: memories of the Impi Yamakhanda. Thohoyandou: Ditlou.

MATHONSI, N.N. 2002. Social commitment in some Zulu literary works published during the apartheid era. Durban: University of Natal. (Unpublished Ph.D. dissertation.)

MOFOLO, T. 1925. Chaka. Lesotho: Morija.

MSIMANG, C.T. 1986. Folktale influence on the Zulu novel. Pretoria: Acacia.

NYEMBEZI, C.L.S. 1971. The use of magic in Vilakazi's novels. African studies, 30:313-339.

SCHEUB, H. 1985. Zulu oral traditions and literature. (In Andrezejewski, B.W., Pilaszewicz, S. \& Tyloch, W. Literatures in African languages. Cambridge: Cambrigde University Press. p. 293-528.)

STUART, J. 1913. A history of the Zulu rebellion. London: Macmillan.

STUART, J. 1922-1926. Zulu readers series: UThulasizwe (1922); UHlangakhula (1924); UBaxoxele (1924); UKhulumethule (1925); UVusezakithi (1926). Pietermaritzburg: Shuter \& Shooter.

VILAKAZI, B.W. 1935a. Inkondlo kaZulu: Bantu treasury. Johannesburg: Wits University Press.

VILAKAZI, B.W. 1935b. Noma nini. Pinetown: Mariannhill Mission Press. 
VILAKAZI, B.W. 1939. UDingiswayo kaJobe. Pinetown: Mariannhill Mission Press.

VILAKAZI, B.W. 1943. Nje nempela. Pinetown: Mariannhill Mission Press.

\section{Key concepts:}

African elite story

African romanticism

converts and traditionalists

magic, use of

past and national identity, reusable

plot, parallel construction

polygamy

\section{Kernbegrippe:}

Afrika keurstorie

Afrika romantisisme

bekeerlinge and tradisionaliste

betowering, gebruik van

intrige, parallelle konstruksie

poligamie

verlede en nasionale identiteit, herinvestering van 